\title{
Törnudd's and Siukonen’s Methodical Starting Points of Music Pedagogy in the Field of Educational Trends
}

\author{
Katri-Helena Rautiainen \\ University of Jyväskylä, Jyväskylä, Finland
}

\begin{abstract}
The purpose of this study is to investigate the effect of educational trends on A. Törnudd's (1913) and V. Siukonen's (1929) methods of music education (teaching and singing) in Finland from 1863 to the late 1930s. In the examination of methods the analysis focuses on the time when Törnudd and Siukonen were influential. A model of analysis was created in the study, with the help of which common and divergent elements in the educational trends and methods of music education were sought. According to the study, Törnudd's pattern singing method represented the Old School starting points, but he was a supporter of the work school, for instance. Siukonen's method was based on the New School principle in which the child-centered education philosophy and the developmental-psychological growth and development were taken into account in developing the method. Siukonen raised singing by ear as a central feature, from which children made observations. Methodical transition period took place at the turn of the 1920s and 1930s. However, in teaching singing, the effects of the new trends were seen as early as from the late 1910 s onwards.
\end{abstract}

Keywords: Old School, New School, Aksel Törnudd, Vilho Siukonen, elementary school, teacher training college, music pedagogy

\section{Introduction}

The purpose of this research is to find out the influence of major educational trends in Finland on Aksel Törnudd's and Vilho Siukonen's methods of teaching of singing (music education). The examination of educational trends focuses between the foundation of the Finnish teacher training college institution in 1863 and the late 1930s. Siukonen's method books, published in 1929, are compared to another significant music pedagogue, Törnudd, who published already in 1913 his singing didactics and a related songbook. Both Törnudd's and Siukonen's methods were used and applied widely in the Finnish elementary schools and teacher training colleges in the early decades of the 20th century (Rautiainen, 2003, pp. 329-330). Hence, comparison of their methods was the object of the study. In addition, the Old and New School educational trends in Finland are also reviewed, as well as their manifestation in the teaching methods of these two pedagogues.

The entire spectrum of educational trends could be seen in Finland in the early decades of the 20th century. In order to clarify their discussion, the author has used the division to Old and New School presented by Lahdes (1961) here. An analysis model was created for the research, with the help of which the impact of these two educational trends on Törnudd's and Siukonen's methods was analyzed. The phenomena found in the school 
system were examined with the help of the created analysis model. On the basis of these general intellectual-historical phenomena, the aim was to inductively come up with a model that guided to search for new information and to analyze and systemize the collected data (Hirsjärvi, Remes, \& Sajavaara, 1997, pp. 140-141).

In this research the phenomenon area includes the New School trends that spread from Europe and America to Finland, and their comparison mostly to the Old School's: (1) teacher-centricity; (2) use of patterns; (3) substantial revision; (4) teaching method based on rote, whose most significant manifestation are; and (5) Herbart-Zillerian formal degrees. After systematization and classification, the: (1) child's psychology (education philosophy arising from the child, child's individuality, development, and hobbies); (2) independent initiative (initiative and independent exercises); (3) work school (manual work besides spiritual work, handicrafts and pottering, "learning by doing” and work notebooks); (4) sociality (pupils' cooperation and social intercourses, group work, open teaching discussion); and (5) getting rid of patterns (no formal degrees, avoiding pattern-oriented methods in teaching, illustrative teaching and the teaching moving on from the known to the unknown arose as the most central features of the New School (Rautiainen, 2003, pp. 103-104; 2011, p. 29; 2012, p. 8), are examined further in "Educational Trends in Finland".

\section{Educational Trends in Finland}

\section{Starting Points of Educational Trends and the Old School}

In Finland the educational discussion and application of these principles into elementary school teaching started fully when Finland's first teacher training college educating elementary school teachers was founded in Jyväskylä in 1863. Uno Cygnaeus (1810-1888) was elected as the founder and developer of the college. Cygnaeus had gotten his educational influences mainly from Central Europe, Germany, and especially from the Wettingen teacher training college in Switzerland (Nurmi, 1964, pp. 41-42; Pajamo, 1976, p. 74). Cygnaeus emphasized the Christian-moral nature and wanted to evoke patriotism. He favored for instance illustrative teaching, wanted to develop activity based on the pupil's own work and aimed at combining practice subjects and knowledge subjects. Cygnaeus was not in favor of excessive cramming or mechanical learning process. The school also had to have an educational impact. Furthermore, teaching should not be too information-centerd (Isosaari, 1961, pp. 88-95; Lahdes, 1966, p. 152). Many of Cygnaeus’ aspirations never reached their fulfillments, because his term of office as the director of the Jyväskylä teacher training college (1863-1868) was short-lived.

Olai Wallin (1832-1896), the college's teacher of education, developed Uno Cygnaeus’ starting points further. Likewise, he aspired to educate his pupils in the Christian-moral spirit and underlined that education is all about developing the child's inborn strengths. Wallin also supported teaching based on perception and independent initiative. He was not keen on mechanical rote, but wanted to develop the pupils' own thinking instead. Like Cygnaeus, Wallin also thought elementary school should provide the pupils with the knowledge and skills that they needed in practical life (Isosaari, 1961, pp. 94-95). Wallin emphasized raising children's emotion and will as well as cognitive teaching. It was also important to pay attention to discipline, as he did not believe in the growth strength of human nature (Suutarinen, 1992, p. 104).

When Finland's first teacher training college opened its doors, Zachris Joachim Cleve (1820-1900) was elected as the professor of pedagogy and didactics. Cleve took Hegel's philosophy and educational principles as his starting point. The influence of his work could clearly be seen in the development of the elementary school system and teacher training colleges. Cleve modified Cygnaeus' suggestion, which can be seen in the 
elementary school decree of 1866. On the other hand, he did not have a major influence on the pedagogy and didactics of the pedagogy teachers of the teacher training college (Isosaari, 1961, pp. 142, 144).

Finland's second teacher training college educating elementary school teachers was founded in Sortavala in 1880. Despite Uno Cygnaeus' opposition, Bruno Boxström (1855-1921) was elected as the teacher of history and pedagogy. Boxström's starting point was a Bible-based Christian philosophy of life. He supported the ambulatory school, because he did not want schools to share too much information to pupils. In Boxtröm's opinion, education and teaching should be based on knowing the development periods. In addition, the teacher's persona was more important than the method (Sortavalan Seminaari 1880-1930, 1930, pp. 47, 99; Suutarinen, 1992, pp. 97-98).

Despite the common aspirations, a common educational view on how to organize the teaching was still lacking. Even the so-called model courses published in 1881 by the school system board failed to fix the problem. Their purpose was to balance the syllabuses of different school subjects. Model courses did not provide clear teaching objectives, and methodological instructions were likewise lacking. There were a lot of information subjects, but they were hardly applied into practice. Lessons were mostly based on homework examination, revision and mechanical rote. Not much time was therefore left for preparing new homework (Lahdes, 1966, p. 154).

The same practical defects continued to exist even after this period, when the Herbart-Zillerian education philosophy began its domination in the late 19th century. Teaching continued to be teacher-centerd and pattern-oriented, but at the same time it provided a clearer structure for the course of the lesson, a sort of pattern to be followed. With the help of these different phases, i.e., patterns, more time was dedicated for learning new things and applying them in practice.

The Herbartian ideas modified by Mikael Soininen (1860-1924) had a crucial impact on this development in Finland. He came up with a unified lesson structure in his books Yleinen kasvatusoppi (1895) and Opetusoppi I-II (1901; 1906). However, it shall be noted that also other representatives of the Herbart-Zillerian school, Tuiskon Ziller, Wilhelm Rein, Friedrich Wilhelm Dörpfeld, and Karl Lange, had their own share in developing the formal degrees of Soininen's didactics (see also Kurvinen, 1960, p. 54; Carnap, 1897, pp. 35, 613). In Soininen's view, the lesson was to be divided into three sections. The first was the degree of perception, which included preparing the teaching, presenting the new issues, and advanced handling. The second degree was the degree of conceptualism, which included the formation of concepts and laws, as well as organizing the formed concepts. The third degree was the degree of practice (Soininen, 1906, pp. 32-153, 157).

The Herbartian influences could also be seen in the reports of the schoolbook commission (1899) lead by Y. K. Yrjö-Koskinen (1854-1917), in which school subjects had cognitive-competent and general significances (Lahdes, 1966, p. 155). He also acted as the teacher of history and pedagogy of the Jyväskylä teacher training college. During this post he developed the alternate course system. In the alternate course system, the first and the second year classes, as well as the third and the fourth year classes, were combined into one homework group that took turns in studying a certain syllabus on alternate years. This practice was used extensively from the 1890s onwards and it remained dominant up until the 1920s. Herbartian pedagogy and didactics provided a fertile soil for its application (Harju, 1988, pp. 292-293).

\section{Reformist Pedagogical Trends}

While Herbart-Zillerian's starting points were arriving in Finland, new educational trends were spreading 
elsewhere in the world. Their common feature was education philosophy springing from the child. The child's individuality was explored by means of experimental psychology. At the end of the 19th century, an art education movement had developed in Germany, its basic idea being “vom Kinde aus” (Lahdes, 1961, pp. 7-8; Grimm, 1915; Kuosmanen, 1915). In the beginning of the 20th century these reformist-pedagogical trends gradually landed in Finland from Europe and America. Initially, they received plenty of attention in articles discussing the educational field in Finland.

For instance, in a column in the 1906, Opettajain Lehti newspaper use the pseudonym Mbg (1906) commented an article by Francois Guex (1861-1918), a Swiss professor. In the article, Guex had divided the educational trends of the turn of the century into four categories. The classical i.e., historical trend aimed at raising the child in the spirit of Comenius and Pestalozzi. Leo Tolstoi (1828-1919) and his school of free education represented the anarchist trend. The New School trend wanted to reform the school into a more practical direction. The scientific direction demanded studies on children which were based on precise perceptions and experiments, as well as pedagogy based on them (Mbg, 1906).

Also in the columns of such newspapers as Kansakoulun Lehti, Työkoulu, and Kasvatus ja Koulu, there was vivid discussion about different New School trends. Especially the work school can be considered one of the most famous and used New School trends in Finland in the 1910s. The starting point was emphasizing the pupils' initiative. In fact, already Cygnaeus' ideas, for instance on the role of handicrafts, were in line with the practices of the early 20th century's work school. Some individuals, such as Kaarle Oksala (1914), the teacher of history and pedagogy in the Jyväskylä teacher training college, and A. K. Ottelin (1916), who wanted to combine the new trend and the Herbartian ideologies. Furthermore, Salo (1926) handled Herbart-Zillerism in his didactics rather superficially and wished that formal degrees would be used flexibly by leaving some parts out or changing the order, so that the most important methodical principle was in accordance with the New School. The work school starting points were met with such great enthusiasm that even some Herbartian supporters became firm supporters of the work school. One of the people who changed their mind was Onni Rauhamaa (1911), who published his ideas in his book in 1911. In his view, information should be sought by means of doing, practical work should be taught as an independent subject besides information, and information-centerd data should be chosen from the realm of the home district (Rauhamaa, 1911, pp. 3, 13-14).

The work school enthusiasm gave inspiration to two remarkable publications by Oskari Mantere (1913) and Väinö Valorinta (1913), which were published in 1913. According to Mantere, the work school movement had two directions: One wanted manual work to become a school subject, while the other wanted to include manual work in every lesson. Valorinta criticized the Old School methods and stated that the child should be treated as an independent and individual person. He also emphasized that teaching and education should be based on experimental research and that work and activity should be the starting points of all teaching. At the same time the emphasis in the learning process shifted from the teacher to the pupil. Work, perception, and experience were the starting points of learning. Valorinta's publication was remarkable, also due to the fact that he applied Finnishness in the New School principles. He encouraged people to read Kalevala and works of Aleksis Kivi. He held art education in great value too (Valorinta, 1913). At the beginning of 1915, Valorinta started editing a paper called Työkoulu, which had been published for a while as an appendix called Työ- ja taidekasvatus in the newspaper Opettajain Lehti. The paper spurred the spreading of the work school ideology and the New School ideas.

At the turn of the 1930s, the Estonian school system received more and more attention in Finland. 
Especially school exhibitions and their work book collections were admired. They were taken into use rather quickly besides actual school books (Lahdes, 1961). All in all, teaching in Finland started to be influenced by an individual working method, its most significant promoter being Sirkkola (1936). She published a didactics in 1936, which was the first school book published in Finland that was based entirely on the principles of the New School. The idea was that pupils got the same exercises that each pupil then did according to his or her individual tendencies. The most important teaching forms were teaching discussion and work instructions suitable for the upper class. In Sirkkola's view, the excess use of work notebooks should be avoided, because they were merely an instrument for learning. Sirkkola's general ambition was to remove the negative spirit of discipline and pattern-oriented teaching method that had been dominant in the elementary school (Sirkkola, 1936).

Despite these reformation aspirations, Soininen's didactics based on Herbartian formal degrees stood their ground in Finnish schools. It was only after the war that Matti Koskenniemi's (1944) didactics put an end to the long domination of Soininen's works (Koskenniemi, 1944; Lahdes, 1966, p. 158). On the basis of these foreign role models, the Finnish experts in education created the educational starting points in the school routines for the country's own national needs. Next, these manifestations of the Old and New School in the singing teaching methods of the music teachers of that time, Aksel Törnudd and Vilho Siukonen, are examined and analyzed.

\section{Starting Points of Törnudd's Pattern Method and Siukonen's Analytic-Synthetic Method}

Aksel Törnudd (1874-1923) worked as the music teacher of Rauma teacher training college (1898-1919) and later on also as the elementary school inspector (1919-1923). His method was based on the scale, the triad and patterns, in which a melody theme of a few notes had been built for each note on the major and minor scale (e.g., in C major: the pattern of Do: do, re, do, re, do; the pattern of Re: re, mi, fa, re, do; the pattern of Mi: mi, fa, mi, fa, re, do; the pattern of Fa: fa, sol, la, sol, mi, re, do etc.) (Törnudd, 1913a, 1913b). Törnudd compiled a rather extensive methodical school book for the purpose of teaching singing. It was published in 1913 by the name Kansakoulun lauluoppi, and it also included a song book. The book served as a teacher's guide. It gave instructions for the songs in the song book and examples on how to teach singing and what matters and aims the teachers should include in their teaching.

Vilho Siukonen (1885-1941), the teacher of singing of the Sortavala teacher training college (1917-1929), called his method an "analytic-synthetic" method, which he introduced in his book Laulun opetusoppi (1929b). He also published a related songbook, Laulukirja (1929a), on the same year. The method starts from a whole song that is broken down into different parts. In teaching, this means that during singing by ear the basic concepts of music, i.e., elements, are studied. Gradually and phase by phase, pupils discover the basic issues that are required for note singing and playing. According to Siukonen, the end result of the analysis is that on the basis of what they hear, pupils learn to detect and mark the duality and triality of beats, simple note durations and learn to distinguish the major and minor. Only later on attention is paid to the pitch and note names on the staff. The teaching progresses by the same principles as above.

According to Siukonen, when learning a song by ear, the analysis exercises may progress for instance in the following way (Siukonen, 1929a, 1929b): (1) Teacher reads the lyrics from the board. Unfamiliar words are explained. One of the pupils reads the lyrics and after that, the whole class reads them together; (2) Teacher sings the song by tapping on the beat notes; (3) Singing together and tapping on the beat notes; (4) Singing the song; (5) Marking the rhythm of an easy verse with notes above the lyrics on the basis of the teacher's singing; 
(6) Recognizing the keynote of the song. The song is sung quietly while the teacher plays the long keynote; and

(7) Singing the song. Singing the keynote, and based on the general impression of the song, the song's triad is sung. The major triad is jolly and it is taken from the song Arvon mekin ansaitsemme. The minor triad is sad, and it is taken from the song Taivas on sininen ja valkoinen.

In Siukonen's method, the analysis is followed by synthesis, i.e., picking out, which can be rhythm or ear training. The starting point to be examined here is a note picture that is interpreted by setting the rhythm with lyrics, by singing, or by playing. In other words, Siukonen's method starts from analysis in which the tune is first divided into sections and individual notes. This is followed by synthesis, in which notes form tunes. (Siukonen, 1929b, p. 6). In practice, in Siukonen's method the musical phenomenon is first understood, i.e., heard, and only after that the phenomenon is transferred into the notated form. The teaching focuses on one matter at a time and the perfect notation is reached only after several exercises. Nowadays this is also known as active listening, in which the hearer's ears are sort of opened phase by phase in order to hear different elements of music. Pupils are advised to pay attention to these matters before the actual listening situation.

The starting point of Siukonen's method is therefore singing by ear, in which musical thinking is not required in the beginning, but rather, everything happens by intuition. First, it is discovered that the song is made up of notes. After that, the force, duration and pitch of the note were examined. Once this had been discovered, it was written up on the board above the lyrics. These exercises are then followed by dictation and picking out exercises (Siukonen, 1929b, pp. 39-40).

In contrast, Törnudd did not use the concepts of analysis and synthesis at all. In this respect, comparisons cannot be made between Siukonen and Törnudd, but there are some essential differences between their methodical starting points. Törnudd built the songs first on the scale and gradually included triads. When the distance between the notes was something else, a pattern assisting the interval was introduced. Issues related to the rhythm were taught only after the melody; whereas Siukonen's method had a reverse order. The starting point was the rhythm of the song and the lyrics rhythm of the text. Only after that the melody was observed. Siukonen started the teaching of music elements and concepts from singing, from which observations were first made by listening and only after that the perceived phenomenon got a name that was written up. Pupils learned Törnudd's songs also by ear, but the musical concepts were given to pupils straight away. Furthermore, patterns were to be learned by heart. However, in Siukonen's teaching these aspects were absent. There were also differences in the way keys were practiced. Törnudd started with keys that had been divided to different year classes. Almost all old keys were revised every other year. Therefore the teaching programme of the first and third, as well as that of the second and fourth year class were almost identical. In Siukonen's teaching the songs were in different keys straight from the beginning. They were not handled until the fourth year class. Before this pupils learned to tell the differences between major and minor songs and their basic triad. Unlike Törnudd, Siukonen's teaching was not based on revising the syllabus of the year classes, but on each year course the new matter was connected to matters that had already been learned. Furthermore, on the third year class note names were introduced, and their teaching was connected to playing harmonium and keyboard. This was absent in Törnudd's teaching. Both Törnudd and Siukonen had ear training exercises. Moreover, Siukonen also had rhythm and note dictation exercises and rhythm training exercises. They both had scale and triad exercises, but in Siukonen's teaching they came along in a later phase in teaching. In Törnudd's classes their practicing started already on the first singing lesson (Törnudd, 1913a, 1913b; Siukonen, 1929a, 1929b). 


\section{Törnudd's and Siukonen's Methods in the Field of Pedagogical Trends and Learning Contents of the Year Classes}

When examining the trends of the Old and New School as well as Törnudd's and Siukonen's methodical starting points, several similarities can be found between them. Getting rid of patterns, excess rote-centerd revision and repetition were among the New School's aspirations. Getting rid of pattern singing can be considered a feature of the New School. Törnudd's method started from learning the melody, in which patterns were not initially needed. The melodies of the songs were, therefore, based on the scale and the triad. Patterns were only learned later on, and they were used in practicing intervals. In this respect Törnudd's method had been influenced by not only the Old School patterns, but also the New School starting points. However, Siukonen did not only want to use the scale and triad system, but also considered this starting point insufficient. Siukonen had to, therefore, create a method that abandoned the melody-centricity of the Old School. Siukonen placed rhythm as the most central starting point of his method. Another essential change was that the children were activated as learners to observe phase by phase the music concepts and theory on the basis of the music they heard. So far the theory had rather been learned by heart. Another Siukonen's methodical change was that songs in different keys could be rehearsed straight from the beginning. In Törnudd's case the patterns forced to handle the songs by keys. First pupils sang songs that were in C major and then songs in A minor. Other keys were introduced later on. This principled change also had an impact on the structure of song books. Törnudd's songs had been grouped according to keys, while Siukonen's songs had been organized by themes. New School features also included Siukonen's rhythm dictation, rhythm training exercises, and note dictation exercises. Another new aspect in Siukonen's method was that teaching progressed with small steps from easy issues to more difficult ones, new content, and depth, was always added to issues that had been learned the previous year. According to Törnudd's Old School principle, the same contents were revised every other year. Only new songs and patterns built on the scale of different keys brought variation. In the comparison of the methods, Siukonen's keyboard pictures representing the keyboard of the harmonium (piano) and pupils' harmonium playing can be considered New School influences, increasing pupil's own activity and functioning as a means of illustration (Törnudd, 1913a, 1913b; Siukonen, 1929a, 1929b).

Siukonen developed the principles of his method so that the child's age and development periods were taken into consideration. According to him, the content to be taught always depended on the children's development stage. Furthermore, teaching should progress in the same order as children were able to conceive different elements of music. This was in fact one of the most remarkable reformations that Siukonen brought into teaching singing, while in Törnudd's time it had been rather foreign and was not, therefore, included in the Old School starting points. In the author's research, Siukonen's development periods were divided into the following age and content periods: (1) perid of rhythtm (at the age of nine, i.e., the 3rd grade); (2) relative period (at the age of 10, i.e., the 4th grade); (3) absolute period (at the age of 11, i.e., the 5th grade); and (4) period of form and harmony (at the age of 12, i.e., the 6th grade). The first school years, i.e., the 1st and 2nd grades of elementary school (ages 7-8) were called the period of song play. According to Siukonen, this period should include a lot of singing by ear, combined with song plays and rhythmic activities (Rautiainen, 2003, pp. 160, 190-192).

The syllabus of the rhythmic period focuses on the basic concepts of music (note force, beat notes, off-beat notes, barline, duality and triality, beat, note and pause). Rhythms and values were illustrated also with 
rhythm syllables (e.g., quarter note $=$ tam, two quavers $=$ tara, and dotted quarter note $=$ tamt). Furthermore, children had rhythm dictation and rhythm training exercises. At the end of the third grade, pupils were prepared for the upcoming year's relative ear training. This included learning the keynote, and major and minor triad, followed by ear training and note dictation exercises.

The syllabus of the relative period continues to broaden tonality, with the main focus on learning singing names and the relative pitch. During this period, dictation and picking-out exercises take turns, theoretical knowledge is extended and time signatures are studied.

The absolute period introduces playing names and solid pitch as the new matters. Pupils get to play little melodies with the harmonium's keys on the fifth grade. The syllabus of this period differs rather lot from the previous one, as pupils now practice all major and minor keys. Singing lesson of the absolute period naturally includes a lot of singing and exercises of the previous period in the form of new songs and exercises.

The period of form and harmony is divided into two phases: practicing musical forms and chords. During this period attention is paid to the song's structure. Harmony is practiced with the help of canons and two-toned songs. When listening to chords, pupils learn to identify dyads, triads, tetrads, and pentads. As in the previous period, the contents of the previous year classes are deepened further.

Törnudd's lesson contents cannot be divided into development periods, because when moving from year class to another, the changes are mostly only changes in keys. The actual content is developed further only within one year class when moving from one lesson to another but that, also, is revised on upcoming grades. It is noteworthy that Törnudd included the study of music theory already on the first school years (1st and 2nd grades). Teaching started with note names (c, d, e, etc.), whose gradual passage, pitch, and the triad were illustrated with the help of ladders. Whole tones and semitones were also illustrated with the help of it. Singing names (do, re, mi, etc.,) were also used besides these and finally placed on the staff. In Siukonen's teaching, on the other hand, the early school years focused on practicing different songs and song plays. From the third grade onwards Törnudd's method included learning values, and singing names were replaced with notes. Sharps and flats were also introduced at this stage. In addition to scale and triad exercises, pupils also started to practice the patterns of $\mathrm{C}$ major and A minor. According to Törnudd, the previous year's theory of music was revised on the fourth grade. The new matters were the new patterns in F, B, and Es, and as major and their relative keys. The third year matters were revised on the fifth year. Octaves were also introduced at this stage. The sixth school year manly focused on the fourth year ambitions. New keys included new patterns in G, D, A, E major, and their relative keys. In Siukonen's teaching note names came along only on the fifth school year so that they were taught in two phases. First pupils learned the notes c, d, e, f, g, and then, a, h, and c. Before this, singing names illustrating the pitch had been used (Törnudd, 1913a, 1913b; Siukonen, 1929a, 1929b).

\section{Conclusions}

The purpose of this paper is to examine the impact of educational trends, the Old and the New School, on Aksel Törnudd's and Vilho Siukonen's methods of music education. Examination focused on method books published by Törnudd in 1913 and Siukonen in 1929. The examination of educational trends is situated between the foundation of the first teacher training college institution in 1863 and the late 1930s. The Old School gave gradually way to the reformist-pedagogical trends in the 1910s. This included, for instance, work school, which got a lot of supporters within the Finnish school system. These trends were also reflected in Törnudd's and Siukonen's methods. 
Törnudd applied Soininen’s Old School formal degrees into the course of the lesson. His teaching method was also mostly based on the Old School starting points, but it also had a touch of influences from the New School. The influence of the Old School could be seen in the method in regards of the fact that music theory and also teaching singing were based on teacher-centerd approach. Teacher taught music theory to children, who had to learn it by heart. The method started with melodies that were built on the scale and the triad. If the scale and the triad were not enough, patterns were used. The influence of the New School could, therefore, be seen when it was not necessary to use patterns. In contrast, the starting point of Siukonen's teaching was based on the aspirations of the New School, taking the child's developmental-psychological starting points into consideration. The whole progression of teaching music was based on considering the child's development. On the basis of that, Siukonen changed the dominant method based on pattern singing. The starting point was now singing by ear, from which the rhythm was first examined. Pitch and harmony came along only later on. Törnudd's exercises were done at the beginning of the lesson as separate exercises without any connection whatsoever to the song to be sung. In contrast, Siukonen combined rhythm, note dictation, rhythm, and ear training exercises with the song to be sung in the lesson. When practicing the pitch, Siukonen first used singing names. He also used them when illustrating the major and minor, whereas Tördnudd used both note names and singing names side by side straight from the beginning. Abundant revision, which was typical of the Old School, could be seen in Törnudd's method when practicing patterns. Likewise, repetition was seen every other year when the same syllabuses were revised. Siukonen's lessons were not based on formal degrees but they varied flexibly according to needs. Furthermore, on each year class the new matter was based on matters learned earlier and then processed further. Finally, the work school starting points could be raised from the New School features and it could be concluded that although its use spread rather quickly to Finnish schools, Siukonen did not give any instructions or comments for its utilization. Apparently he did not consider the workbook method necessary in music teaching. On the other hand, the very idea of work school was learning by doing and increasing the pupils' spontaneous practicing, which as such were included also in Siukonen's methodical starting points. In contrast, Törnudd considered the work school principles rather important. However, it becomes apparent only from his articles, in which he rather over-flowingly supports the implementation of the work school ideology at school (Törnudd, 1915a, 1915b).

Although Törnudd's method was mostly based on the Old School starting points, it can be considered a remarkable step forward in the development of Finnish music teaching. At the same time Törnudd's singing didactics was the first method book applied for Finnish needs, in which educational starting points had been applied. On the one hand, Törnudd's didactics was extensive and versatile by its contents. It gave plenty of practical examples on the course of the lesson and progression of the method on different class years. It was therefore met with enthusiasm in Finnish teacher training colleges. The versatility of the book may have had a major influence on how Törnudd's didactics was used even after the publication of Siukonen's didactics in 1929. On the other hand, the methodical revolution started in Finland already at the turn of the 1920s and 1930s, at the same when patterns were gradually abandoned. It is noteworthy that the Old School principles were abandoned in music teaching (singing) at least a decade before the 1940s, which has been suggested by Lahdes (1961). It shall also be noted that the influences of new trends in teaching singing could be seen at least ever since the late 1910s. Through his articles and presentations and his work as the music teacher of Sortavala teacher training college, Siukonen had made his method famous before the actual publication of his didactics. Therefore, the seed of reformation had been planted a lot earlier. At the same time, the work had paved the way 
for a new change and development, the roots of which reach up until today's music teaching.

This year 2013 is the Finnish teacher training college's 150th jubilee year. At the same time, the University of Jyväskylä will return to its roots of origin, where the far-reaching foundation of the Finnish school system was laid, and on which the acclaimed education system was later created and developed. This development was greatly influenced by Törnudd and Siukonen, whose methodical starting points of music inspired critical discussion in the music teaching pedagogy of their time, and at the same time they give us an example on how the pedagogical trends also contributed to the development of methods of teaching singing.

\section{References}

Carnap, A. (1897). Friedrich wilhelm dörpfeld. Gütersloh: C. Bertelsmann.

Grimm, L. (1915). The work school’s predecessors (Työkouluaatteen edeltäjät!). Opettajain Lehti, 9, 115.

Harju, M. (1988). Supervision of rural elementary schools in 1861-1921 (Maalaiskansakoulujen tarkastustoimi vuosina 1861-1921). Studia Historica Jyväskyläensia, 38.

Hirsjärvi, S., Remes, P., \& Sajavaara, P. (1997). Study and write (Tutki ja kirjoita) (3rd ed.). Tampere: Tamper-Paino Oy.

Isosaari, J. (1961). Teaching of educational sciences and didactics in the Jyväskylä teacher training college in 1865-1901 (Jyväskylän seminaarin kasvatus_ja opetusopin opetus vuosina 1865-1901). Jyväskylän kasvatusopillisen korkeakoulun julkaisuja , 25.

Koskenniemi, M. (1944). Elementary school’s didactics (Kansakoulun opetusoppi ). Helsinki: Otava.

Kuosmanen, R. (1915). Pezzlozzista as the father of the work school (Pestalozzista työkoulun isänä). Opettajain Lehti, 16, 210-212.

Kurvinen, O. (1960). The formal degrees of Mikael Soininen’s didaktics (Mikael Soinisen opetusopin muodolliset asteet). In M. A. Sainio (Ed.), Mikael Soininen 3.11.1860-12.3.1924 (pp. 48-63). Jyväskylän Kasvatusopillisen Korkeakoulun julkaisuja, 22.

Lahdes, E. (1961). Influence of the new school on Finland's elementary schools (Uuden koulun vaikutus Suomen kansakouluun). Helsinki: Otava.

Lahdes, E. (1966). Development lines of didactics (Didaktiikan kehityslinjoja). In A. Valtasaari, A. Henttonen, L. Järvi, \& V. Nurmi (Eds.), Elementary school 1866-1966 (Kansakoulu 1866-1966) (pp. 151-172). Helsinki: Otava.

Mbg, E. V. (1906). Modern educational trends (Nykyajan kasvatusopilliset suunnat). Opettajain Lehti, 9, 85-87.

Nurmi, V. (1964). Birth and development of teacher training colleges in Finland in the last century II: Didactic Part (Maamme seminaarien varsinaisen opettajakoulutuksen synty ja kehittyminen viime vuosisadalla II: Didaktinen osa). Jyväskylä Studies in Education, Psychology, and Social Research, 7.

Pajamo, R. (1976). Teaching of singing in Finnish schools 1843-1881 (Suomen koulujen laulunopetus vuosina 1843-1881). Acta musicologica fennica, 7, Diss. Helsinki.

Rauhamaa, O. (1911). An act of the principle to be applied in a primary school education (Teon periaatteen sovelluttamisesta kansakoulun opetukseen). Helsinki: Otava.

Rautiainen, K.-H. (2011). Influence of pedagogical trends on Aksel Törnudd's and Vilho Siukonen’s music pedagogy. J. Davidova (Ed.). Problems In Music Pedagogy, 9, 27-41.

Rautiainen, K.-H. (2012). Comparing A. Törnudd's and V. Siukonen’s music lesson structures from the perspective of educational trends. In T. Selke, G. Lock, M. Môistlik, \& P. Beaudoin (Eds.), The changing face of music and art education. Interdisciplinary Journal for Music and Art Pedagogy, 4(1), 7-15.

Rautiainen, K-H. (2003). External and internal structure of singing lessons: Aksel Törnudd (1874-1923) and Wilho Siukonen (1885-1941) as developers of methods of teaching singing at teacher training colleges and elementary schools 1893-1941 (Laulutunnin ulkoinen ja sisäinen rakenne: Aksel Törnudd (1874-1923) ja Wilho Siukonen (1885-1941) seminaarien ja kansakoulun laulunopetusmenetelmien kehittäjinä 1893-1941). The Sibelius-Academy. Studia Musica 19. Joensuu: Joensuun yliopistopaino.

Salo, A. (1926). Primary school’s didactics I (Alakansakoulun opetusoppi I). Yleiset opetusopilliset suuntaukset. Helsinki: Otava.

Sirkkola, M. (1936). The work school: Experiments for reforms of elementary schools (Oman työn koulu: Kokeita kasakoulun uudistamiseksi). Helsinki: WSOY.

Siukonen, V. (1927). Different conceptions on the basic questions of teaching singing in schools (Erilaisia käsityksiä koulun laulunopetuksen peruskysymyksistä). The jubilee for Ilmari Krohn 8.11.1927 (Juhlakirja Ilmari Krohn’ille 8.11.1927). Helsinki: Suomen Musiikkitieteellinen Seura. 
Siukonen, V. (1929a). Song book: Songs for the home and the school (Laulukirja: Koulun ja kodin lauluja). Helsinki: Otava. Siukonen, V. (1929b). Didactics of singing (Laulun opetusoppi). Helsinki: Otava.

Soininen, M. (1895). General didactics (Yleinen kasvatusoppi). Helsinki: Otava.

Soininen, M. (1901). Didactics I (Opetusoppi I). Helsinki: Otava.

Soininen, M. (1906). Didactics II (Opetusoppi II). Helsinki: Otava.

Sortavalan seminaari 1880-1930 (The Sortavala Teacher Training Collega 1880-1930). (1930). Helsinki: Valistus.

Suutarinen, S. (1992). Herbartian pedagogical reformation: In Finland's elementary schools at the beginning of the century (1900-1935) (Herbartilainen pedagoginen uudistus: Suomen kansakoulussa vuosisadan alussa (1900-1935)). Jyväskylä Studies in Education, Psychology And Social Research, 90.

Törnudd , A. (1915a). About the teaching of singing I (Laulunopetuksesta. I). Työkoulu, 1, 6-8.

Törnudd, A. (1913a). Theory of teaching singing in elementary schools (Kansakoulun lauluoppi). Porvoo: WSOY.

Törnudd, A. (1913b). School's song book (Koulun laulukirja). Porvoo: WSOY.

Törnudd, A. (1915b). About the teaching of singing II (Laulunopetuksesta. II). Työkoulu, 2, 24-27.

Valorinta, V. (1913). The new school's marks (Uuden koulun merkkejä). Porvoo: WSOY.

Weber, E. (1915). What is a “work school”? II (Mitä on ”työkoulu”? II). Kansakoulun Lehti, 226-227.

Wolgast, H., \& Götze, C. (1915). What is a “work school”? III (Mitä on “työkoulu”? III). Kansakoulun Lehti, 287-289. 